
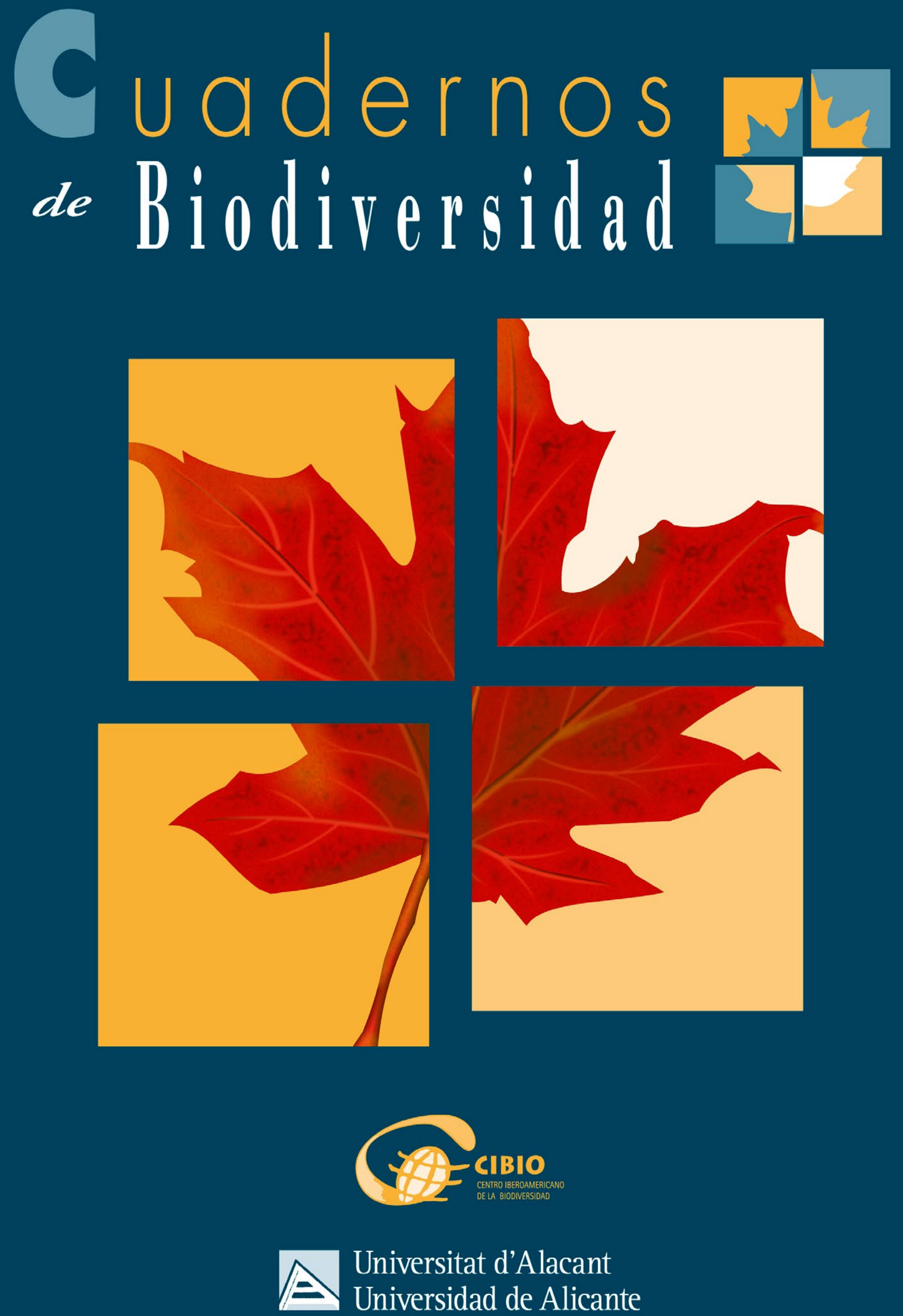


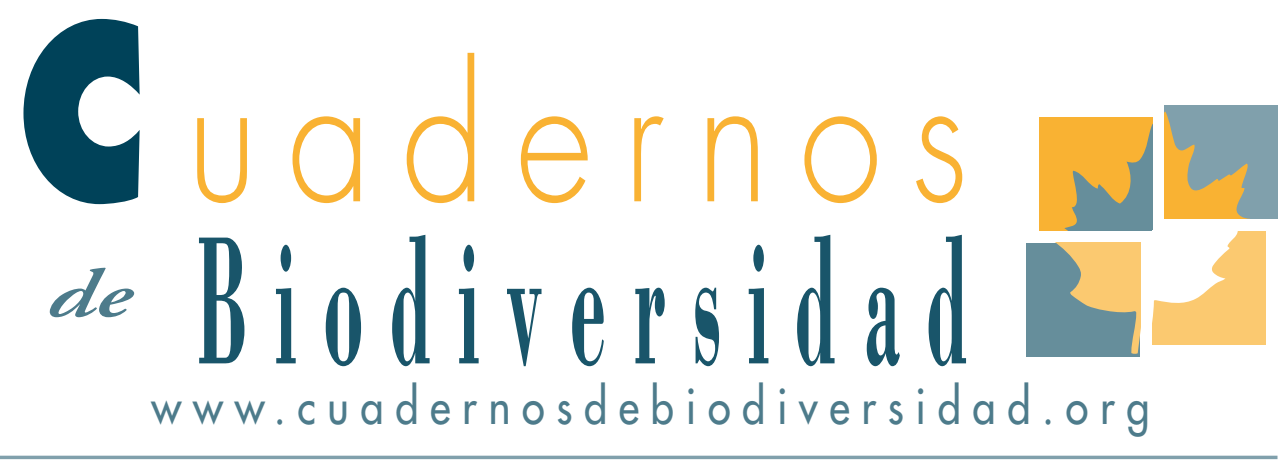

\section{Interspecies gene flow is a key evolutionary process for the adaptation of long-lived species to new environmental conditions}

\section{R. Lumaret ${ }^{1}$}

I AVE. PAUL PARGUEL, 34090, MONTPELLIER, FRANCE. EMAIL:ROSELYNE.LUMARET@GMAIL.com

\section{RESUMEN}

La especiación por hibridación y la hibridación introgresiva entre especies del mismo género se reconocen cada vez más como un mecanismo que contribuye a la generación de novedades evolutivas y a la promoción de amplitud de nicho ecológico. En especies de larga vida caracterizadas por una evolución lenta, el flujo génico interespecífico puede constituir un proceso adaptativo más eficiente que la fijación de mutación. Este supuesto se evalúa a partir de una gran muestra de estudios de casos sobre hibridación natural en las denominadas plantas y animales Matusalén. La longevidad favorece las variables del comportamiento de apareamiento a largo del tiempo y según las condiciones locales, puede explicar las altas tasas de hibridación observadas regularmente en estas especies. En raras ocasiones, la hibridación da como resultado la creación de especies híbridas poliploides y homoploides compuestas por individuos que muestran segregación transgresiva de los rasgos parentales. Se ha demostrado que mediante hibridación introgresiva, se transfieren frecuentemente grandes conjuntos de nuevos alelos de una especie a otra, a veces codificantes para caracteres adaptativos importantes, aumentando así el potencial evolutivo de las poblaciones afectadas sin alterar la integridad de las especies, haciendo que la hibridación introgresiva sea el mecanismo evolutivo más efectivo para responder a los principales cambios ambientales en especies de larga vida. Se aportan sugerencias para mejorar las estrategias de conservación de estas especies mediante la evaluación del potencial evolutivo de las zonas híbridas y la identificación de las poblaciones capaces de responder al rápido cambio climático.

Pallabras clave: Flujo génico interspecifico, adaptación, especie de largo ciclo de vida. 


\section{ABSTRACT}

Hybrid speciation and introgressive hybridization between congeneric species are being increasingly recognised as important contributors to the generation of evolutionary novelty and to the promotion of niche-width expansion. In long-lived species characterized by slow evolution, interspecific gene flow may constitute a more efficient adaptive process than mutation fixation. This assumption is evaluated from a large survey of case studies regarding natural hybridization in Methuselah plants and animals. Longevity which favours variable mating behaviours over time and according to local conditions may explain the high hybridization rates observed regularly in these species. On rare occasions, hybridization resulted in the creation of polyploid and homoploid hybrid species composed of individuals showing transgressive segregation of parental traits. More frequently, large sets of new alleles, sometimes coding for important adaptive characters, were shown to be transferred from one species to another through introgressive hybridization, thus increasing the evolutionary potential of the concerned populations without altering species integrity, making introgressive hybridization the most effective evolutionary mechanism to respond to major environmental changes in long-lived species. Suggestions are made to improve the conservation strategies for these species by evaluating the evolutionary potential of hybrid zones and identifying the populations able to respond to rapid climate change.

Key words: Interspecies gene flow, adaptation, long-lived species.

\section{INTRODUCTION}

It is generally accepted that species' survival depends directly on their ability for adaptive evolution that is also a key component of range expansion (Pfennig et al., 2016). In each species, populations survive environmental change due to the production of alleles and epialleles for traits that are adaptive to the new environment. These may arise by mutation or from gene flow from conspecific populations or related taxa. This phenomenon of interspecies hybridization is now considered to be widespread in plants and animals (Abbott et al., 2013). It generally occurs according to the scenario schematised in Figure 1. First generation hybrid individuals (F1) are produced from the initial cross between two parental species. In the absence of polyploidization which may create an immediate reproductive isolation between the hybrids and their parent species, the F1 individuals usually backcross to parent genotypes at a much higher frequency than hybrid individuals (Yakimowski \& Rieseberg, 2014). Continued mating of the fittest genotypes (i. e., those with the highest fecundity) with parental genotypes is recognised as an important process for interspecific gene exchange (Yakimowski \& Rieseberg, 2014; Canestrelli et al., 2016). If genome stabilisation occurs after a few backcross generations, homoploid hybrid species may arise, providing they develop sufficient reproductive isolation and/or they can colonise niches unavailable to their parents. Extensively repeated backcrossing, a phenomenon known as introgressive hybridization, may ultimately result in the transfer of new alleles and epialleles, and/or novel gene combinations between the hybridising species, and increase genetic variation that can then be selected to augment fitness.

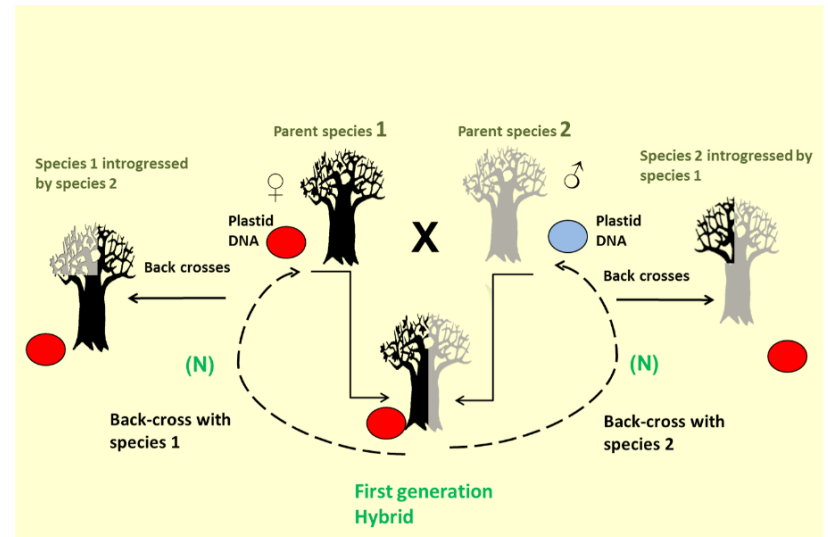

Figure 1. Schematic scenario showing initial hybridization and subsequent multiple $(\mathrm{N})$ back-cross generations between species. In this scenario, maternal plastid DNA inheritance is assumed. 
According to theoretical predictions (Orr \& Unckless, 2008), local adaptation to environmental change, more particularly at the range edge, is unlikely to result from mutations because of the considerable time necessary for the occurrence and the spread of favourable mutations in the concerned populations. Conversely, local adaptation is theoretically expected and has indeed been found to result mostly from admixture, more particularly from the hybridization of congeneric species (Abbott et al., 2013; Stelkens et al., 2014). In recent years, interspecific admixture involving repeated introgression in contact areas has been shown to be a facilitator of species range expansion by creating genetic variation that allows populations to adapt to selective pressures, either through the transfer of specific adaptive alleles, the selection of novel gene-combinations facilitating evolutionary innovation, or through the local increase of genetic and epigenetic diversity that allows the persistence of threatened populations (or species) and/or the creation of the conditions for further adaptation (Bräutigam et al., 2013; Pfennig et al., 2016).

In plants as in animals, most long-lived species are large organisms characterized by slow rates of evolution, when compared to species with faster generation turnover (Smith \& Donoghue, 2008; Thomas et al., 2010). In addition to genetic inertia due to low replacement rates in the populations, the slow molecular evolution observed in long-lived species has been mainly attributed to the accumulation of lethal mutations during life (Zhong et al., 2014). Interspecies gene flow through hybridization could therefore be expected to be crucial for adaptation to rapid environmental changes in these species.

In the present review, this assumption is evaluated from a large survey of case studies in long-lived plants and animals. More specifically, the review addresses the following questions: (1) Is interspecies hybridization frequent and widespread in these species? (2) What are the main evolutionary outcomes of hybridization in terms of speciation and genetic introgression?, (3) How effective are interspecific isolation barriers with respect to hybridization?, (4) What do we know about the adaptive effect of interspecific gene flow in long-lived species, and (5) What are the impacts of human-induced environ- mental disturbances and climate change on natural interspecific hybridization on these species? The final objective is to inventory current scientific knowledge regarding the natural evolution of long-lived species in order to guide their conservation, while preserving and making the best use of their adaptive potential, particularly in view of their survival in the context of changing climate.

\section{IS INTERSPECIES HYBRIDIZATION FRE- QUENT AND WIDESPREAD IN LONG- LIVED SPECIES?}

In the present survey, case studies reporting natural interspecies hybridization identified or confirmed by using molecular data were considered in millenary and centenary species, except in those characterized by exclusive or very predominant clonal reproduction. For animals, case studies regarding species living 50 years or more were also included (Table 1). For vertebrate species, lifespans refer to Carey $\&$ Judge (2000). As the species concept is not uniform in plants as in animals, in a few cases indicated with asterisks in the table 1 , hybridization between long-lived subspecies or ecotypes were added to the list, as they clearly share many characteristics with species, such as genetic and ecological differences, as well as assorting mating. A good example is provided by genus Orcinus (killer whales) that formally comprised a single cosmopolitan species including several well differentiated ecotypes which were considered to be distinct species by several authors (Morin et al., 2010; Riesch et al., 2012). Finally, the numerous case studies regarding human-mediated contacts between species (e. g. controlled crosses or unintentional introduction of non-native species) were not considered in the survey.

Table 1. Total number of millenary $(\mathrm{M})$, centenary $(\mathrm{C})$, and long-lived animal species (L) involved in interspecific hybridization as inferred from molecular analysis, with their genus and organism type. In each genus, the number of new allopolyploid and homoploid species resulting from hybridization, introgressive hybridization cases, and evidence for adaptive variation $(+)$ are also shown (see the text for details). 


\begin{tabular}{|c|c|c|c|c|c|c|c|}
\hline Genus & $\begin{array}{l}\text { Life } \\
\text { span }\end{array}$ & $\begin{array}{l}\text { Species } \\
\text { No }\end{array}$ & $\begin{array}{l}\text { Polyploid } \\
\text { species }\end{array}$ & $\begin{array}{l}\text { Homoploid } \\
\text { species }\end{array}$ & $\begin{array}{l}\text { Introgressive } \\
\text { hybridization }\end{array}$ & $\begin{array}{l}\text { Adaptive } \\
\text { variation }\end{array}$ & Reference \\
\hline Osmunda (fern) & $\mathrm{C}$ & 5 & 1 & $3(\mathrm{e})$ & 1 & - & [1-3] \\
\hline Polysticum (fern) & $\mathrm{C}$ & 4 & - & - & 2 & + & {$[4-5]$} \\
\hline Araucaria (conifer) & $\mathrm{C}$ & 4 & - & - & 2 & - & {$[6]$} \\
\hline Taxus (yew / conifer) & $\mathrm{M}$ & 3 & - & - & 2 & - & [7] \\
\hline Cupressus (cypress/ conifer) & $\mathrm{C} / \mathrm{M}$ & 2 & - & - & 2 & - & {$[8]$} \\
\hline Juniperus (juniper/ conifer) & $\mathrm{C}$ & 21 & - & - & 9 & - & [9-14] \\
\hline Larix (larch/ conifer) & $\mathrm{C} / \mathrm{M}$ & 5 & - & - & 3 & - & {$[15-16]$} \\
\hline Abies (fir / conifer) & $\mathrm{C}$ & 10 & - & - & 4 & - & [17-22] \\
\hline Picea (spruce/ conifer) & $\mathrm{C}$ & 10 & - & $1(\mathrm{a})$ & 6 & + & [23-30] \\
\hline Pinus (pine/ conifer) & $\mathrm{C}$ & 20 & - & $3(\mathrm{a})$ & 8 & + & [31-41] \\
\hline Adansonia (baobab) & $\mathrm{M}$ & 4 & - & $1(\mathrm{a})$ & 4 & + & {$[42]$} \\
\hline Platanus (plane tree) & $\mathrm{M}$ & 3 & - & - & 2 & - & {$[43]$} \\
\hline Ficus (fig tree) & $\mathrm{C} / \mathrm{M}$ & 9 & - & - & 4 & - & {$[44-46]$} \\
\hline Olea (olive tree) & $\mathrm{C} / \mathrm{M}$ & $4^{*}$ & 1 & - & 1 & - & {$[47-48]$} \\
\hline Fraxinus (ash tree) & $\mathrm{C}$ & 2 & - & - & 1 & + & {$[49-52]$} \\
\hline Fagus (beech tree) & $\mathrm{C}$ & $2^{*}$ & - & - & 1 & - & [53-54] \\
\hline Quercus (oak tree) & $\mathrm{C}$ & 42 & - & 2(b) & 22 & + & {$[55-73]$} \\
\hline Betula (birch tree) & $\mathrm{C}$ & 5 & 1 & - & 3 & - & [74-75] \\
\hline Eucalyptus (eucalyptus) & $\mathrm{C}$ & 42 & - & - & 31 & + & [76-81] \\
\hline Populus (poplar tree) & $\mathrm{C} / \mathrm{M}$ & 13 & - & - & 8 & + & [82-92] \\
\hline Yucca (agave) & $\mathrm{C}$ & $4^{*}$ & - & 1(b) & 1 & - & [93-94] \\
\hline Opuntia (cactus) & $\mathrm{C}$ & 20 & 10 & - & - & - & {$[95-96]$} \\
\hline Strongylocentrotus (urchin) & $\mathrm{L}$ & 2 & - & - & 1 & - & {$[97-98]$} \\
\hline Bathymodiolus (mussel) & $\mathrm{L}$ & 4 & - & - & 2 & + & [99-101] \\
\hline Anguilla (eel) & $\mathrm{L}$ & 2 & - & - & 1 & - & [102-103] \\
\hline Sebastes (rockfish) & $\mathrm{L}$ & 15 & - & - & 8 & - & [104-111] \\
\hline Acipenser (sturgeon) & $\mathrm{L} / \mathrm{C}$ & 20 & 11 & - & - & - & {$[112]$} \\
\hline Somniosus (shark) & $\mathrm{C}$ & 2 & - & - & 1 & - & {$[113]$} \\
\hline Crocodylus (crocodile) & $\mathrm{L}$ & 2 & - & - & 1 & - & {$[114]$} \\
\hline Chelonoidis (giant tortoise) & $\mathrm{C}$ & 2 & - & - & 1 & - & [115-116] \\
\hline ChelonialEretmochelys (turtle) & $\mathrm{L}$ & 4 & - & - & 3 & - & [117-118] \\
\hline Emys (terrapin) & $\mathrm{L}$ & $4+2^{*}$ & - & - & 3 & - & [119-120] \\
\hline Trachemys (terrapin) & $\mathrm{L}$ & 10 & - & - & 4 & - & {$[121]$} \\
\hline Larus (gull) & $\mathrm{L}$ & 3 & - & - & 2 & - & [122-123] \\
\hline Phoebastria (albatross) & $\mathrm{L}$ & 2 & - & - & 1 & & {$[124]$} \\
\hline Amazona (parrot) & $\mathrm{L}$ & $2^{*}$ & - & - & 1 & - & {$[125]$} \\
\hline Psittacus (parrot) & $\mathrm{L}$ & $2^{*}$ & - & - & 1 & - & {$[126]$} \\
\hline Balaenoptera (whale) & $\mathrm{L} / \mathrm{C}$ & 2 & - & - & 1 & - & {$[127]$} \\
\hline Globicephala (pilot whale) & $\mathrm{L}$ & 2 & - & - & 1 & - & [128-129] \\
\hline Orcinus (killer whale) & $\mathrm{L} / \mathrm{C}$ & $2^{* *}$ & - & - & 1 & - & [130-131] \\
\hline Stenella (dolphin) & $\mathrm{L}$ & 2 & - & $1(\mathrm{c})$ & 1 & - & [132] \\
\hline Loxodonta (elephant) & $\mathrm{L}$ & 2 & - & - & 1 & - & [133] \\
\hline Ursus (bear) & $\mathrm{L}$ & 2 & - & - & 1 & - & [134] \\
\hline Pan (chimpanzee) & $\mathrm{L}$ & 2 & - & - & 1 & - & {$[135]$} \\
\hline Homo (human) & $\mathrm{L} / \mathrm{C}$ & 2 & - & - & 1 & + & [136-138) \\
\hline
\end{tabular}


${ }^{*}$ Subspecies, ${ }^{* *}$ Ecotypes (see the text for details). Origin of reproductive isolation between homoploid hybrid and parent species: habitat divergence (a), temporal divergence (b), assortative mating behaviour (c), geographic isolation (d), unknown (e).

References: 1. Yatabe et al., 2009; 2. Tsutsumi et al., 2011; 3. Sigel, 2016; 4. Mullenniex et al., 1998; 5. Kentner et al., 2000; 6. Gaudeul et al., 2014; 7. Möller et al., 2013; 8. Little, 2004; 9. Palma-Otal et al., 1983; 10. Adams \& Kistler, 1991; 11. Terry et al., 2000; 12. Terry, 2010; 13. Adams, 2015; 14. Adams et al., 2017; 15. Wei \& Wang, 2003; 16. Semerikov \& Lascoux, 2013; 17. Isoda et al., 2000; 18. Semerikova et al., 2011; 19. Bella et al., 2014; 20. Cinget et al., 2015; 21. Xiang et al., 2015; 22. Krajmerova et al., 2016; 23. Krutovskii \& Bergmann, 1995; 24. Jaramillo-Correa \& Bousquet, 2005; 25. Du et al., 2011; 26. Hamilton \& Aitken, 2013; 27 Hamilton et al., 2013; 28. Sun et al., 2014; 29. Ran et al., 2015; 30. Tsuda et al., 2016; 31. Matos et al., 2000; 32. Epperson et al., 2003; 33. Watano et al., 2004; 34. Ma et al., 2006; 35. Delgado et al., 2007; 36. Ito et al., 2008; 37. Wang et al., 2011; 38. Gao et al., 2012; 39. Ren et al., 2012; 40. Cullingham et al., 2012; 41. Wachowiak et al., 2016; 42. Leong Pock Tsy et al., 2013; 43. Grimm \& Denk, 2008; 44. Parrish et al., 2003; 45. Moe \& Weiblen, 2012; 46. Wei et al., 2014; 47. Besnard et al., 2008; 48. Besnard et al., 2013; 49. Heuertz et al., 2006; 50. Gerard et al., 2006a; 51. Gerard et al., 2006b; 52. Gerard et al., 2013; 53. Papageorgiou et al., 2008; 54. Oh et al., 2016; 55. Staudt et al., 2004; 56. Dodd \& Afzal-Rafii, 2004; 57. Kanno et al., 2004; 58. Cavender-Bares et al., 2005; 59. Mir et al., 2006; 60. Salvini et al., 2008; 61. Lumaret \& Jabbour-Zahab, 2009; 62. Penaloza- Ramirez et al., 2010; 63. Lepais et al., 2010; 64. Neophytou et al., 2011; 65. Moran et al., 2012; 66. Welter et al., 2012; 67. Mhamdi et al., 2013; 68. Guichoux et al., 2013; 69. Lepais et al., 2013; 70. Lagache et al., 2014; 71. Valencia-Cuevas et al., 2015; 72. Rellstab et al., 2016; 73. Ortego et al., 2017; 74. Zohren et al., 2016; 75. Tsuda et al., 2017; 76. McKinnon et al., 2004a; 77. McKinnon et al., 2004b; 78. Field et al., 2010; 79. Grattapagia et al., 2012; 80. Bradbury et al., 2016; 81. Larcombe et al., 2016; 82. Vanden Broeck et al., 2005; 83. Hamzeh et al., 2007; 84.
Lexer et al., 2010; 85. Macaya-Sanz et al., 2011; 86. Lindtke et al., 2012; 87. Geraldes et al., 2014; 88. Wang et al., 2014; 89. Jiang et al., 2016; 90. Christe et al., 2016; 91. Suarez-Gonzalez et al., 2016; 92. Christe et al., 2017; 93. Rentsh \& Leebens-Mack, 2012; 94. Starr et al., 2013. 95. Majure et al., 2012; 96. Realini et al., 2015; 97. Addison \& Hart, 2005; 98. Harper et al., 2007; 99. O’Mullan et al., 2001; 100. Faure et al., 2009; 101. Johnson et al., 2013; 102. Pujolar et al., 2014; 103. Wielgoss et al., 2014; 104. Roques et al., 2001; 105. Buonaccorsi et al., 2005; 106. Hawkins et al., 2005; 107. Valentin et al., 2006; 108. Pampoulie \& Danielsdottir, 2008; 109. Buenaccorsi et al., 2011; 110. Artamonova et al., 2013; 111. Sahat et al., 2017; 112. Havelka et al., 2011; 113. Hussey et al., 2015; 114. PachecoSierra et al., 2016; 115. Chiari et al., 2009; 116. Poulakakis et al., 2015; 117. Vilaça et al., 2012; 118. Kelez et al., 2016; 119. Spinks \& Shaffer, 2009; 120. Raemy et al., 2017; 121. Parham et al., 2013; 122. Sternkopf et al., 2010; 123. Sonsthagen et al., 2016; 124. Rohwer et al., 2014; 125. Lopes et al., 2007; 126. Melo \& O'Ryan, 2007; 127. Hatch et al., 2006; 128. Miralles et al., 2013; 129. Miralles et al., 2016; 130. Pilot et al., 2010; 131. Riesch et al., 2012; 132. Amaral et al., 2014; 133. Ishida et al., 2011; 134. Cahill et al., 2015; 135. Manuel (de) et al., 2016; 136. Sánchez-Quinto \& Lalueza-Fox, 2015; 137. Racimo et al., 2015; 138 Juric et al., 2016.

As shown in Table 1, interspecific hybridization involves a large range of plant and animal species and is particularly high in genera Juniperus, Abies, Picea and Pinus (conifers), Quercus, Eucalyptus and Populus (hardwood trees), Opuntia (cactus), Sebastes and Acipenser (fish genera) and Trachemys (terrapin). All these genera include numerous long-lived species. The number of species indicated in Table 1 is probably an underestimate owing to the large number of interspecific hybridizations reported in the past, exclusively on the basis of morphology, e. g. in oaks (Rushton, 1993). Moreover, in long-lived plant and animal species, e. g. in oaks (Staudt et al., 2004) and in geoemydid turtles (Fujii et al., 2014), natural hybridization between exotic and congeneric native or naturalised species has often been reported 
to occur relatively rapidly after the known time of introduction, indicating a favourable aptitude for hybridization.

Theory predicts that, besides species intrinsic properties regarding pre-zygotic barriers and postzygotic isolation forces (see Vallejo-Marin \& Hiscock, 2016, for a review), interspecies hybridization depends on environmental factors, more specifically the habitat and climate conditions, determining the relative abundance of species and the relative frequency of gametes involved in intra- and interspecific reproduction (Cannon \& Lerdau, 2015; Klein et al.,2017). In long-lived species predominantly consisting of large primarily outcrossing organisms with slow replacement rate (see above), under unfavourable environmental conditions, individual's survival is generally favoured over their reproductive investment (Bromham, 2011). As reported by Morris et al. (2008), the presence of a persistent adult stage should allow long-lived species to better tolerate yearly fluctuations in reproduction, including local or occasional fecundity decrease, which may result from inter-species hybridization in contact areas. In addition, longevity should increase the opportunity to produce interspecific hybrids from highly compatible parental individuals.

\section{OUTCOMES OF HYBRIDIZATION IN LONG-LIVED SPECIES}

As also reported for shorter-lived organisms (Mallet, 2008), hybridization rarely leads to speciation in long-lived species (Table 1). Speciation by allopolyploidy is restricted to very few species of ferns of the genus Osmunda (Sigel, 2016) and hardwood trees, namely in Olea (Besnard et al., 2008) and Betula (Tsuda et al., 2017), but is generalised in Opuntia (cactus) (Majure et al., 2012). In animals, this mode of speciation is found exclusively in sturgeons where it has been confirmed for most the species of the Acipenser genus (Mable et al., 2011 and references therein). Fish are generally reported to be prone to form reproductively successful hybrids and, except in Salmonidae, the allopolyploid origin of numerous species, specifically those that reproduce in freshwater environments, has been confirmed and was attributed to environmental variability during the breeding season that should increase the production of unreduced gametes (Mable et al., 2011).

In long-lived plant species, homoploid hybrid speciation was reported in several genera, with a single hybrid species identified in most of them, except in ferns, pines and oaks, where a maximum of three homoploid species were formally identified (Table 1). In long lived animals, a single case of homoploid speciation has been documented in a dolphin genus (Amaral et al., 2014). Homoploid hybrid speciation is considered to be rare both in plants and animals, likely because it requires several restrictive conditions, i.e., the arising of a stable, fertile and reproductively isolated hybrid lineage without change in chromosome number (Vallejo-Marin \& Hiscock, 2016). Reproductive isolation between parental and hybrid taxa may be achieved by diverse evolutionary processes. Habitat divergence was identified as the isolating factor in several homoploid hybrid species, e.g., in Picea purpurea Mast. (Sun et al., 2014), Pinus densata Mast. (Wang et al., 2011), P. funebris Kom., P. takahasii Nakai (Ren et al., 2012), and in Adansonia alba Jum. \& H. Perr. (Leong Pock Tsy et al., 2013). A change in flowering phenology compared to the parental species was observed in Quercus afares Pomel (Mir et al., 2006) and Yucca gloriosa L. (Rentsch \& Leebens-Mack, 2012), whereas ethological isolation was suggested for Stenella clymene Cray (the clymene dolphin) (Amaral et al., 2014) (Table 1). As reported by Mavárez \& Linares (2008), detecting hybrid species still remains a challenge despite the numerous genetic resources available for testing their occurrence, including the possibility of analysing DNA from fossils, and in spite of the effective statistical methods developed recently to distinguish hybridization from incomplete lineage sorting (Wen et al., 2016). Hybrid species are lineages with mixed ancestry and their identification depends on the use of diagnostic markers whose rate is expected to increase with divergence between the parental hybridizing species while the probability of successful interspecific cross increases with species' genetic relatedness. Moreover, identifying the source of reproductive isolation of homoploid species needs coordinated multidisciplinary approaches combining genetic, morphological, geographical 
and eco-physiological data, which explains why few groups of long-lived organisms have been the subject of such detailed investigation to date.

Introgressive hybridization is by far the most common outcome of hybridization in long-lived species and it involves a large range of plant and animal genera (Table 1). In several case studies reported recently, e.g., in the genera Araucaria (Gaudeul et al., 2014), Picea (Halmilton \& Aitken, 2013), Anguilla (Wielgos et al., 2014) and Phoebastria (albatross) (Rohwer et al., 2014), introgressive hybridization was either revealed or confirmed decisively by using high-resolution cytoplasmic and nuclear molecular markers (e. g. DNA sequencing in very recent years) in the analysis of the same individuals, in combination with their morphological variation and geographic distribution. Introgressive hybridization was often observed in secondary contacts between congeneric species and was associated with past or current range expansions during which gene introgression is theoretically expected to occur, predominantly from the resident species to the invading one (Currat et al., 2008). By using cytoplasmic markers, this prediction was verified in several longlived taxa, namely between Phoenobastria nigripes Audubon and P. immutabilis Rothschild (Rohwer et al., 2014), Quercus suber L. and Q. ilex L. (Lumaret \& Jabbour-Zahab, 2009 and references therein), in three pairs of Eucalyptus species (Mc Kinnon et al., 2004a, 2004b), and between Populus fremontii S. Watts. and P. angustifolia James (Currat et al., 2008 and references therein). In their genetic analysis of hybrid zones between two spruce species, Du et al. (2011) reported that introgression was very significant and occurred from Picea likiangensis (franch.) E. Pritz (the resident species) into P. purpurea Mast. (the expanding species) for the maternally inherited mitochondrial (mt) DNA characterized by low gene flow via seeds. However, bidirectional and more limited introgression was identified for chloroplast (cp) DNA paternally inherited and transmitted at a higher rate, thus suggesting that the extent of introgression varies according to the rate of intraspecific gene flow. For nuclear markers, the prediction of Currat et al. (2008) was verified in several empirical studies regarding long-lived species, e.g. between Anguilla anguilla L. and $A$. rostrata Lesueur (Wielgos et al., 2014), between Populus fremontii S. watts. and P. angustifolia James (Currat et al., 2008 and references therein), or between Betula pubescens Ehrh (a tetraploid invading species) and two diploid resident species, B. nana L. and B. pendula Roth (Zohren et al., 2016). In oaks, similar rates of bidirectional nuclear introgression were obtained on average between Quercus suber L. and Q. ilex L. when the species were analysed over their whole range, but substantial variation was identified according to loci and contact areas (Lumaret \& Jabbour-Zahab, 2009). The direction of introgression between Quercus robur L. and Q. petrae (Matt.) Liebl. which are sympatric European oak species was also found to match the theoretical prediction but exclusively at loci influenced by selection (outlier loci). These would therefore be more appropriate to make inferences about past demographic processes than non-outlier loci (Guichoux et al., 2013).

\section{HOW EFFECTIVE ARE THE INTERSPECI- FIC ISOLATING BARRIERS IN LONG- LIVED SPECIES?}

In several recent studies, both intrinsic and extrinsic factors acting as either pre-zygotic or post-zygotic barriers were shown to contribute to the maintenance of long-lived species boundaries, although their respective strength may vary between the first- and later generation hybrids. For instance, a strong assortative mating pattern acting as a prezygotic barrier was discovered in first-generation hybrids between Pinus pumila and P. parviflora, as the combined result of flowering time differences and cross incompatibility (Ito et al., 2008). Genetic introgression between the two species was the consequence of a breakdown of these prezygotic barriers and the occurrence of unselective mating in the subsequent generations through backcrossing between hybrids and parental species (Ito et al., 2008). In oaks, as compared to post-zygotic barriers (germination rate and early survival), prezygotic barriers (specifically gametic incompatibility), were shown to be predominantly responsible for reproductive isolation between the species (Lepais et al., 2013). Conversely, in poplars and eucalypts, intrinsic post-zygotic 
barriers were revealed to be strong and persistent in advanced-generation hybrids, accounting for most reproductive isolation in these tree species (Larcombe et al., 2016; Christe et al., 2016). In animals, reproductive isolation is mostly due to prezygotic barriers, more particularly to geographical isolation which increases genetic differentiation (Faure et al., 2009; Pujolar et al., 2014), habitat segregation, as observed in rockfishes (Buonaccorsi et al., 2011), and mating behaviour, as revealed in the gulls of the Larus complex (Sonsthagen et al., 2016). In these last species, the reinforcement of prezygotic barriers was identified as being the result of past episodes of hybridization inducing the selection of protective barriers against hybridization.

\section{IS HYBRIDIZATION AN EFFICIENT PROCESS FOR THE GENERATION OF ADAPTIVE VARIATION IN LONG-LIVED SPECIES?}

As a consequence of a mixture between very different parental genomes, large amounts of genetic variation and new genetic combinations potentially of functional significance are expected to occur in the genomes of early-generation hybrids. As admixed populations return to equilibrium, this genetic variation decreases substantially and stabilizes through the fixing of chromosomal blocks, leading to genomes characterized by stable admixed ancestry over subsequent generations (see Ungerer et al., 1998 for details). During the process, the transgressive segregation of parental traits may promote the development of characters outside the parental phenotypic range in hybrid populations/species that allow them to thrive in new environments.

In long-lived species, the transgressive segregation of parental characters was invoked to explain the extreme morphological characteristics of the hybrid dolphin species Stenella clymene Gray (Amaral et al., 2014), and the unique ecological traits and the extreme habitats of Pinus densata Mast. In this last species, ecological divergence was considered to be a more important driver than geographical isolation (Mao \& Wang, 2011). When grown in a common garden and analysed for several metabolic functions (volatile terpene emissions, freezing tolerance), Quercus afares Pomel, a deciduous oak species derived from hybridization between an evergreen species, Q. suber L., and a deciduous species, $Q$. canariensis Willd. (Mir et al., 2006), was revealed to possess extreme physiological traits indicative of better adaptation to cold conditions as compared with its parental species (Cavender-Bares et al., 2005; Welter et al., 2012). Moreover, the species was reported to be more sensitive to excessive soil moister than $Q$. canariensis Willd., its deciduous parent species (Teissier et al., 1994). The hybrid species currently grows in the lowest part of the altitudinal distribution of Q. canariensis $\mathrm{L}$., which occupies many upper sites characterised by low temperatures and very high precipitation rates, specifically in early spring (Messaoudène et al., 2007). Thus, in Q. afares Pomel, the transgressive segregation of parental traits for cold adaptation likely did not contribute to reproductive isolation which is currently provided by an intermediate flowering time of the hybrid species between those of its parents. The transgressive traits observed in $Q$. afares Pomel may constitute an evolutionary potential to thrive in colder and drier environments in the event of climate change.

Although introgressive hybridization is relatively common in long-lived species, its adaptive significance has been demonstrated in a restricted number of case studies and rarely in animals (Table 1). Most of the early studies were based on the finding of true diagnostic alleles between two ecologically divergent hybridizing species and required extensive sampling from both species' natural ranges. Therefore, many early analyses of hybrid zones between long-lived species were conducted with a restricted number of genetic markers and, most often, without linkage information. In these studies, e. g. in ferns (Kenter et al., 2000), spruces (Hamilton et al. 2013), poplars (Vanden Broek et al., 2005 and references therein), ash tree species (Gerard et al., 2013), mussels (Faure et al., 2009), eucalypts (Mc Kinnon et al., 2010) and pine species (Cullingham et al., 2012), parallel morphological and genetic clines showing variation according to loci and indicative of allele filtering were obtained in replicated transects along environmental gradients, suggesting an important role for extrinsic selection in the genetic structuring and maintenance 
of hybrid zones between long-lived species. In recent years, the development of genetic mapping of species differences and the application of novel analytical techniques to molecular data have provided access to a genome wide panel of codominant nuclear markers. As a consequence, the detection of adaptive genetic variation in hybrid zones was substantially improved with the possibility to identify large numbers of candidate loci for local adaptation (outlier loci), including markers sourced from expressed sequence tags (EST-derived markers) coding for known functional traits. Thus, in a secondary contact between two recently diverged North American poplar species, combined genomic and functional approaches were performed on pure and admixed populations. Evidence of adaptive introgression was obtained from the direct association between the introgression of a Populus balsamifera L. (balsam poplar) DNA fragment containing alleles for local adaptation into $P$. trichocarpa Torr. \& A. Gray (black cottonwood) and the simultaneous expression of the corresponding adaptive traits in the latter species (Suarez-Gonzalez et al., 2016). Moreover, J. Degner presented the results from a recent study of genomic clines in a mosaic hybrid zone between Picea engelmannii Parry and P. glauca (Moench) Voss in Western Canada (Holliday et al. (2017). Disproportionate introgression of single nucleotide polymorphism markers (SNPs) related to climate variables were found in hybrid individuals and, in a given environment, these hybrids possessed disproportionately introgressed alleles from the parental species that best matched their habitat. For genus Homo, complex statistical methods were recently developed to identify archaic introgressed fragments in the genome sequences of modern humans. Strong evidence of the adaptive genetic introgression of Neanderthal DNA sequences into the modern human gene pool was obtained for several genes involved in various metabolic functions, e. g., defence against pathogens, pigmentation, response to hypoxia at high elevations and lipid catabolism (see Racimo et al., 2015 for a review). Despite recurrent gene exchanges within contact zones, specific genomic regions remain refractory to interspecies gene flow so that the genetic differences characterizing parental species identity are maintained, as shown by detailed investigations in several case studies, e. g., in poplars (Christe et al., 2016), oaks (Ortego et al., 2017), rockfishes (Buonaccorsi et al., 2011) and gulls (Sonsthagen et al., 2016).

\section{IMPACTS OF HUMAN-INDUCED EN- VIRONMENTAL DISTURBANCES AND CLIMATE CHANGE ON INTERSPECIFIC HYBRIDIZATION.}

Beyond introductions of exotic species (not considered in this review), different forms of anthropogenic disturbance (land-use alterations, habitat disturbance) and climate change have been shown to facilitate the formation of hybrids in long-lived species by eroding premating reproductive isolating barriers, in accordance with the Anderson \& Stebbins' (1954) disturbance hypothesis. For instance, in oaks, Ortego et al. (2017) found a significant increase in hybridization between Quercus durata Jeps. and $Q$. berberidifolia Liebm. with increasing wildfire frequency. Recent forest destruction was also considered to be responsible for higher hybridization between the forest elephant (Loxodonta cyclotis Matschie) and the savannah elephant ( $L$. Africana Cuvier) (Ishida et al., 2011), and between several sea turtle species due to the warming of their nesting beaches and that caused drastic local population collapses (Vilaça et al., 2012). During past and current global warming episodes, several cases of hybridization occurred between the polar bear (Ursus maritimus Phipps) and the grizzly bear ( $U$. $\operatorname{arctos} \mathrm{L}$.) following the northward expansion of the grizzly bear's range (Cahill et al., 2015). Recent sea warming was also considered to be responsible for an increase in introgressive hybridization in rockfish (Sahat et al., 2017) and in pilot-whales by creating overlaps between the species' habitats during the reproduction season (Miralles et al., 2016).

\section{CONCLUSIONS AND OUTLOOK}

For any species, phenotypic plasticity and migration constitute the most immediate responses to environmental changes, including global warming, as shown recently in European white oaks (Truffaut 
et al., 2017). An effective adaptive evolutionary response or evolutionary rescue is necessary to respond to more persistent and/or drastic environmental changes and allow long-term species persistence (Gonzalez et al., 2012). However, theory predicts that, even in species characterized by large populations and with minimal stochastic effects, population rescue will take a minimum of 25 generations (Bell \& Gonzalez, 2009), making species with long generation times unsuitable for such evolutionary recovery (Vander Wal et al., 2013) leading some authors to recommend assisted migration to facilitate gene flow in long-lived species (Carlson et al., 2014). Recently, introgressive hybridization has been suggested to have the potential to generate the diversity necessary to respond more rapidly to a changing environment, and the identification, genetic study and conservation of hybridization zones was advocated as a useful management option to preserve species' evolutionary potential (Baskett \& Gomulkiewicz, 2011; Hamilton \& Miller, 2016).

The numerous case studies examined in the present review clearly show that natural hybridization is widespread in long-lived species, specifically in plants, although its importance is probably underestimated in animals (Hedrick, 2013). This review also indicates that interspecies hybridization rarely results in new polyploid and homoploid species but, when it does, they are often comprised of individuals showing transgressive segregation of parental traits. Much more frequently, large sets of new alleles at multiple loci, sometimes coding for important adaptive characters, were shown to be transferred from one species to another through introgressive hybridization, increasing the evolutionary potential of the concerned populations, without alteration of species integrity. Evolutionary change was often exhibited within a few generations, possibly making introgressive hybridization the most effective evolutionary mechanism for response to major environmental changes by long-lived species. These species are mostly comprised of large organisms that constitute ecologically and economically important species (e. g. forest and fruit trees and large animals, including several threatened species), thus justifying particular attention in conservation programs. Owing to increased rates of climate change, conservation strategies should consider, in addition to parent species, current hybridization zones, and after they have been identified by using molecular markers, all of the populations derived from past introgressive hybridization and which predominantly exhibit advanced-generation hybrids (i. e. cryptic genetic variation as exemplified in Fig. 2). In addition, the evolutionary potential of the populations derived from hybridization should be evaluated carefully by conducting coordinated genetic and eco-physiological studies so that the conservation of the genetic resources best able to respond effectively to major environmental changes can be prioritized. Thereby, natural, adaptive evolution of long-lived species can be facilitated and appropriate genetic resources be available for rescue operations for endangered species or for the rational management of new areas e.g., by reforestation.

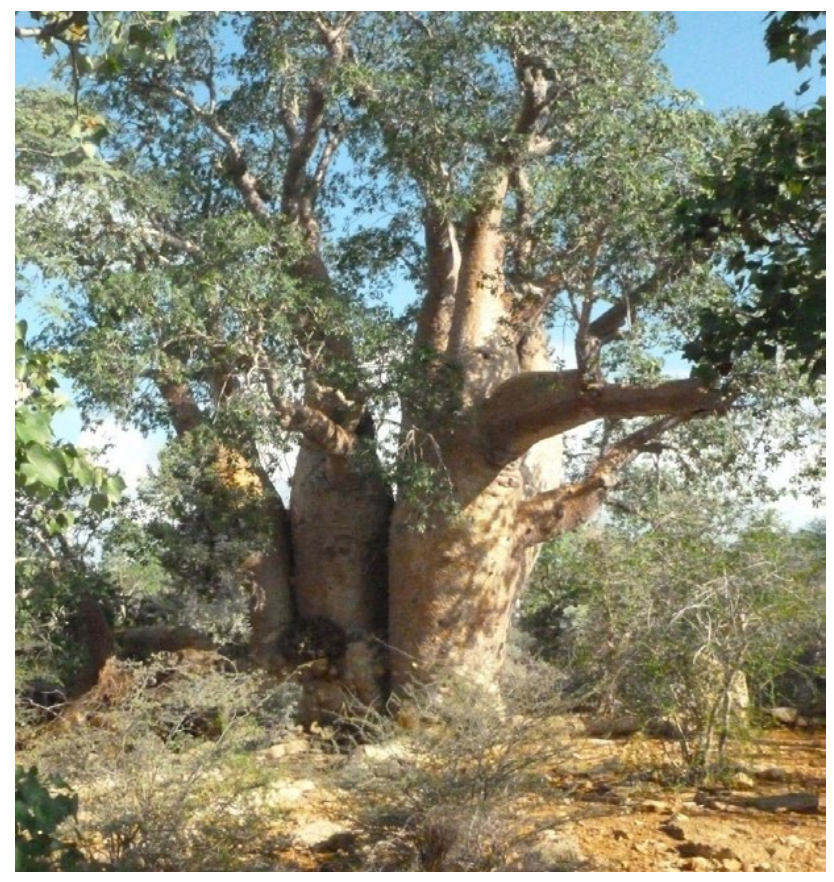

Figure 2. Cryptic genetic variation in the baobabs of Madagascar: this very large, millenary tree grows in the Adansonia rubrostipa Jum. \& H. Perrier population of the Tsimanampetsotse National Park, along the southwestern coast of the island (Patrut et al., 2015). By using nuclear microsatellites as markers, the tree was revealed to be one of the several second-generation hybrids between A. rubrostipa and A. za Baill. identified at the site. Both parental species are endemic to the island, have distinct geographical ranges and differ in important adaptive traits (Leong Pock Tsy et al., 2013). (Photo: R. Lumaret) 


\section{ACKNOWLEDGMENTS}

I am very grateful to Gregory T. Sullivan for useful comments that greatly improved the manuscript.

\section{REFERENCES}

Abbott, R., Albach, D., Ansell, S., Arntzen, J.W., Baird, S.J.E. et al. (2013). Hybridization and speciation. Journal of Evolutionary Biology, 26: 229-246.

Adams, R.P. (2015). Allopatric hybridization and introgression between Juniperus maritima. R. P. Adams and J. scopulorum Sarg. II. Additional evidence from nuclear and cpDNA genes in Montana, Wyoming, Idaho and Utah. Physiologia, 97: 187-196.

Adams, R.P., González-Elizondo, M. S., GonzálezElizondo, M., Ramírez Noya, D. \& Schwarzbach, A.E. (2017). DNA sequencing and taxonomy of unusual serrate Juniperus from Mexico: chloroplast capture and incomplete lineage sorting in J. coahuilensis and allied taxa. Physiologia, 99: 62-73.

Adams, R.P. \& Kistler, J.R. (1991). Hybridization between Juniperus erythrocarpa Cory and Juniperus Pinchotii Sudworth in the Chisos Mountains, Texas. The Southern Naturalist, 36: 295-301.

Anderson, E. \& Stebbins, G.L. 1954. Hybridization as an evolutionary stimulus. Evolution, 8: 378-388.

Addison, J.A. \& Hart, M.W. (2005). Colonization, dispersal, and hybridization influence phylogeography of North Atlantic sea urchins (Strongylocentrotus droebachiensis). Evolution, 59: 532-543.

Amaral, A.R., Lovewell, G., Coelho, M.M., Amato, G. \& Rosenbaum, H.C. (2014). Hybrid speciation in a marine mammal: the Clemene Dolphin (Stenella clymene). PLoS ONE 9(1): e83645. Doi: 10.1371/ journal.pone.0083645.

Artamonova, V.S., Makhrov, A.A., Karabanov, D.P., Rolskiy, A.Y., Bakay, Y.I. \& Popov, V.I. (2013). Hybridization of beaked redfish (Sebastes mentella) with small redfish (Sebastes viviparus) and diversification of redfish (Actinopterygii: Scorpaeniformes) in the Irminger sea. Journal of Natural History, 47: 25-28.

Baskett, M.L. \& Gomulkiewicz, R. (2011). Introgressive hybridization as a mechanism for species rescue. Theoretical Ecology, 4: 223-239.
Bell, G. \& González, A. (2009). Evolutionary rescue can prevent extinction following environmental change. Ecology Letters, 12: 942-948.

Bella, E., Liepelt, S., Parducci, L. \& Drouzas A.D. (2015). Genetic insights into the hybrid origin of Abies $\mathrm{x}$ borisii-regis Mattf.. Plant Systematics and Evolution, 301: 749-759.

Besnard, G., Garcia-Verdugo, C., Rubio De Casas, R., Treier, U.A., Galland, N. \& Vargas, P. (2008). Polypoidy in the olive complex (Olea europaea): evidence from flow cytometry and nuclear microsatellite analyses. Annals of Botany, 101: 25-30.

Besnard, G., El Bakkali, A., Haouane, H., Baali-Cherif, D., Moukli, A. \& Khadari, B. (2013). Population genetics of Mediterranean and Saharan olives: geographic patterns of differentiation and evidence of early generations of admixture. Annals of Botany, 112: 1293-1302.

Bradbury, D.B., Grayling, P.M., MacDonald, B., Hankinson M. \& Byrne, M. (2016). Clonality, interspecific hybridization and inbreeding in a rare mallee eucalypt, Eucalyptus absita (Myrtaceae), and implications for conservation. Conservation Genetics, 17: 193-205.

Bräutigam, K., Vining, K.J., Lafon-Placette, C., Fossdal, C.G., Mirouze, M. et al. (2013). Epigenetic regulation of adaptive response of forest tree species to the environment. Ecology and Evolution, 3: 399-415.

Bromham, L. (2011). The genome as a life-history character: why rate of molecular evolution varies between mammal species. Philosophical Transactions of the Royal Society B, 366: 2503-2513.

Buonaccorsi, V.P., Kimbrell, C.A., Lynn, E.A. \& Vetter, R.D. (2005). Limited realized dispersal and introgressive hybridization influence genetic structure and conservation strategies for brown rockfish Sebastes auriculatus. Conservation Genetics, 6: 697-713.

Buonaccorsi, V.P., Narum, S.R., Karkoska, K.A., Gregory, S., Deptola, T. \& Weimer, A.B. (2011). Characterization of genomic divergence island between black-and-yellow and gopher Sebastes rockfishes. Molecular Ecology, 20: 2603-2618.

Cahill, J.A., Stirling, I., Kistler, L., Salamzade, R., Ersmark, E., et al. (2015). Genomic evidence of geographically widespread effect of gene flow from polar bears into brown bears. Molecular Ecology, 24: 1205-1217. 
Canestrelli, D., Porretta, D., Lowe, W.H., Bisconti, R., Carere, C. \& Nascetti, G. (2016). The tangled evolutionary legacies of range expansion and hybridization. Trends in Ecology \& Evolution, 31: 677688.

Cannon, C.H. \& Lerdau, M. (2015). Variable mating behaviors and the maintenance of tropical biodiversity. Frontiers in Genetics, 6: 183. Doi: 10.3389/gene.2015. 00183.

Carey, J.R. \& Judge, D.S. (2000). Longevity records: Life spans of mammals, birds, amphibians, reptiles and fish. Odense University Press, Denmark, 241 p.

Carlson, S.M., Cunningham, C.J. \& Westley, P.A.H. (2014). Evolutionary rescue in a changing world. Trends in Ecology \& Evolution, 29: 521-530.

Cavender-Bares, J., Cortes, P., Rambal, S., Joffre, R., Miles, B. \& Rocheteau, A. (2005). Summer and winter sensitivity of leaves and xylem to minimum freezing temperatures: a comparison of co-occurring Mediterranean oaks that differ in leaf lifespan. New Phytologist, 168: 597-612.

Chiari, Y., Hyseni, C., Fritts, T.H., Glaberman, S., Marquez, C. et al. (2009). Morphometric parallel genetics in a newly discovered and endangered taxon of Galápagos tortoise. PLos ONE 4(7): e6272. Doi: 10.1371/journal.pone.0006272.

Christe, C., Stölting, K. N., Bresadola, L., Fussi, B., Heinze, B. et al. (2016). Selection against recombinant hybrids maintains reproductive isolation in hybridizing Populus species despite F1 fertility and recurrent gene flow. Molecular Ecology, 25: 2482-2498.

Christe, C., Stölting, K. N., Paris, M., Fraïsse, C., Bierne, N. \& Lexer, C. (2017). Adaptive evolution and segregating load contribute to the genomic landscape of divergence in two tree species connected by episodic gene flow. Molecular Ecology, 26: 59-76.

Cinget, B., De Lafontaine, G., Gérardi, S. \& Bousquet, J. (2015). Integrating phylogeography and paleoecology to investigate the origin and dynamics of hybrid zones: insights from two widespread North American firs. Molecular Ecology, 24: 2856- 2870.

Cullingham, C.I., James, P.M.A., Cooke, J.E.K. \& Coltman, D.W. (2012). Characterizing the physical and genetic structure of the lodgepole pine $\mathrm{x}$ jack pine hybrid zone: mosaic structure and differential introgression. Evolutionary Applications, 5: 879-891.
Currat, M., Ruedi, M. Petit, R.J. \& Excoffier, L. (2008). The hidden side of invasions: massive introgression by local genes. Evolution, 62: 1908-1920.

Delgado, P., Salas-Lizana, R., Vázquez-Lobo, A., Wegier, A., Anzidei, M. et al. (2007). Introgressive hybridization in Pinus montezumae Lamb and Pinus pseudostrobus Lindl. (Pinaceae): morphological and molecular (cpSSR) evidence. International Journal of Plant Sciences, 168: 861-875.

Dodd, R.S. \& Afzal-Rafii, Z. (2004). Selection and dispersal in a multispecies oak hybrid zone. Evolution, 58: 261-269.

Du, F.K., Peng, X.L., Liu, J.Q., Lascoux, M., Hu, F.S. \& Petit R.J. (2011). Direction and extent of organelle DNA introgression between two spruce species in the Qinghai-Tibetan Plateau. New Phytologist, 192: 10241033.

Epperson, B.K., Chung, M.G. \& Telewski, F.W. (2003). Spatial pattern of allozyme variation in a contact zone of Pinus ponderosa and P. Arizona (Pinaceae). American Journal of Botany, 90: 25-31.

Faure, B., Jollivet, D., Tanguy, A., Bonhomme, F. \& Bierne, N. (2009). Speciation in the deep sea: multilocus analysis of divergence and gene flow between two hybridizing species of hydrothermal vent mussels. PloS ONE 4(8): e6485.doi: 10.1371/journal.pone.0006485.

Field, D.L., Ayre, D.J., Whelan, R.J. \& Young, A.G. (2010). Patterns of hybridization and asymmetrical gene flow in hybrid zones of the rare Eucalyptus aggregata and E. rubida. Heredity, 106: 841-853.

Fortini, P., Di Marzio, P. \& Di Pietro, R. (2015). Differentiation and hybridization of Quercus frainetto, Q. petraea, and Q. pubescens (Fagaceae): insights from macro-morphological leaf traits and molecular data. Plant Systematics and Evolution, 301: 375-385.

Fujii, R., Ota, H. \& Toda, M. (2014). Genetic and morphological assessments of hybridization between two non-native geoemydid turtles, Mauremys reevesii and Mauremys mutica, in Northcentral Japan. Chelonian Conservation and Biology, 13: 191-201.

Gao, J., Wang, B., Mao, J.F., Ingvarsson, P., Zeng, Q.Y. \& Wang, X.R. (2012). Demography and speciation history of the homoploid hybrid pine Pinus densata on the Tibetan Plateau. Molecular Ecology, 21: 4811-4827. 
Gaudeul, M., Gargner, M.F., Thomas, P. Ennos, R.A. \& Hollingsworth, P.M. (2014). Evolutionary dynamics of emblematic Araucaria species (Araucariaceae) in New Caledonia: nuclear and chloroplast markers suggest recent diversification, introgression, and a tight link between genetics and geography within species. $B M C$ Evolutionary Biology: 14: 171.

Geraldes, A., Farzaneh, N., Grassa, C.J., McKown, A.D., Guy, R.D., Mansfield, S.D., Douglas, C.J. \& Cronk, Q.C.B. (2014). Landscape genomics of Populus trichocarpa: the role of hybridization, limited gene flow, and natural selection in shaping patterns of population structure. Evolution, 68: 3260-3280.

Gerard, P.R., Fernández-Manjarres, J.F. \& FrascariaLacoste, N. (2006a). Temporal cline in a hybrid zone population between Fraxinus excelsior L. and Fraxinus angustifolia Vahl. Molecular Ecology, 15: 3655-3667.

Gerard, P.R., Klein, E.K., Austerlitz, F., FernandezManjarrés, J.F. \& Frascaria-Lacoste N. (2006b). Assortive mating and differential male mating success in an ash hybrid zone population. BMC Evolutionary Biology, 6:96 doi: 10.1186/1471-2148-6-96.

Gerard, P.R., Temunovic, M., Sannier, J., Bertolino, P., Dufour, J. et al. (2013). Chilled but not frosty: understanding the role of climate in the hybridization between the Mediterranean Fraxinus angustifolia Vahl and the temperate Fraxinus excelsior L. (Oleaceae) ash trees. Journal of Biogeography, 40: 835-846.

Gonzalez, A., Ronce, O., Ferriere, R. \& Hochberg, M.E. (2012). Evolutionary rescue: an emerging focus at the intersection between ecology and evolution. Philosophical Transactions of the Royal Society B, 368: 20120404.

Grattapaglia, D., Vaillancourt, R.E., Shepherd, M., Thumma, B.R., Foley, W., et al. (2012). Progress in Myrtaceae genetics and genomics: Eucalyptus as the pivotal genus. Tree Genetics \& Genomes, 8: 463-508.

Grimm, G.W. \& Denk, T. (2008). ITS evolution in Platanus (Platanaceae): homoeologues, pseudogenes and ancient hybridization. Annals of Botany, 101: 403419.

Guichoux, E., Garnier-Géré, P., Lagache, L., Lang, T., Boury, C. \& Petit, R.J. (2013). Outlier loci highlight the direction of introgression in oaks. Molecular Ecology, 22: 450-462.

Hamilton, J.A. \& Aitken, S.N. (2013). Genetic and morphological structure of a spruce hybrid (Picea sitchensis $\mathrm{x} P$. glauca) zone along a climatic gradient. American Journal of Botany, 100: 1651-1662.
Hamilton, J.A., Lexer, C. \& Aitken, S.N. (2013). Differential introgression reveals candidate genes for selection across a spruce (Picea sitchensis $\mathrm{x} P$. glauca) hybrid zone. New Phytologist, 197: 927-938.

Hamilton, J.A. \& Miller, J.M. (2016). Adaptive introgression as a resource for management and genetic conservation in a changing climate. Conservation Biology, 30: 33-41.

Hamzeh, M., Sawchyn, C., Périnet, P. \& Dayanandan, S. (2007). Asymmetrical natural hybridization between Populus deltoides and P. balsamifera (Salicaceae). Canadian Journal of Botany, 85: 1227-1232.

Harper, F.M., Addison, J.A. \& Hart, M.W. (2007). Introgression versus immigration in hybridizing highdispersal echinoderms. Evolution, 61: 2410-2418.

Hatch, L.T., Dopman, E.B. \& Harrison, R.G. (2006). Phylogenetic relationships among the baleen whales based on maternally and paternally inherited characters. Molecular Phylogenetics \& Evolution, 41: 12-27.

Havelka, M., Kašpar, V. Hulák, M. \& Flajšhans, M. (2011). Sturgeon genetics and cytogenetics: a review related to ploidy levels and interspecific hybridization. Folia Zoologica, 60: 93-103.

Hawkins, S.L., Heifetz, J., Kondzela, C.M., Pohl, J.E., Wilmot, R.L. et al. (2005). Genetic variation of rougheye rockfish (Sebastes aleutianus) and shortraker rockfish (S. borealis) inferred from allozymes. Fish Bulletin, 103: 524-535.

Hedrick, P.W. (2013). Adaptive introgression in animals: examples and comparison to new mutation and standing variation as sources of adaptive variation. Molecular Ecology, 22: 4606-4618.

Heuertz, M., Carnevale, S., Fineschi, S., Sebastiani, F., Hausman, J.F. et al. (2006). Chloroplast DNA phylogeography of European ashes, Fraxinus sp. (Oleaceae): roles of hybridization and life history traits. Molecular Ecology, 15: 2131-2140.

Holliday, J.A., Aiken, S.N., Cooke, J.E.K., Fady, B. \& Gonzalez-Martinez, S.C. et al. (2017). Advances in ecological genomics in forest trees and applications to genetic resources conservation and breeding. Molecular Ecology, 26: 706-717.

Hussey, N.E., Cosandey-Godin, A., Walter, R.P., Hedges, K.J., VanGerwen-Toyne, M. et al. (2015). Juvenile Greenland sharks Somniosus microcephalus (Block \& Schneider, 1801) in the Canadian Artic. Polar Biology, 38: 493-504. 
Ishida, Y., Oleksyk, T.K., Georgiadis, N.J., David, V.A., Zhao, K. et al. (2011). Reconciling apparent conflicts between mitochondrial and nuclear phylogenies in African elephants. PLoS ONE 6(6): e20642. Doi:10.1371/journal.pone.0020642.

Ito, M., Suyama, Y., Ohsawa, A. \& Watano, Y. (2008). Airborne-pollen pool and mating pattern in a hybrid zone between Pinus pumila and P. parviflora var. pentaphylla. Molecular Ecology, 17: 5092-5103.

Isoda, K., Shiraishi, S., Watanabe, S. \& Kitamura, K. (2000). Molecular evidence of natural hybridization between Abies veitchii and A. homolepis (Pinaceae) revealed by chloroplast, mitochondrial and nuclear DNA markers. Molecular Ecology, 9: 1965-1974.

Jaramillo-Correa, J.P. \& Bousquet, J. (2005). Mitochondrial genome recombination in the zone of contact between two hybridizing conifers. Genetics, 17: 1951-1962.

Jiang, D., Feng, J., Dong, M., Wu, M.D., Mao, K. \& Liu, J. (2016). Genetic origin and composition of a natural hybrid poplar Populus $\mathrm{x}$ Jrtyschensis from two distantly related species. BMC Plant Biology, 16: 89.

Johnson, S.B., Won, Y-J., Harvey, J.B.J. \& Vrijenhoek, R.C. (2013). A hybrid zone between Bathymodiolus mussel lineages from eastern Pacific hydrothermal vents. BMC Evolutionary Biology, 13: 21.

Juric, I, Aeschbacher, S. \& Coop, G. (2016). The strength of selection against Neanderthal introgression. PloS Genet 12 (11): e1006340. Doi: 10.1371/journal. pgen. 1006340.

Kelez, S., Velez-Zuazo, X. \& Pacheco, A.S. (2016). First record of hybridization between green Chelonia mydas and hawksbill Eretmochelys imbricata sea turtles in the Southeast Pacific. PeerJ 4: e1712; Doi 10.7717/ peerj. 1712 .

Kentner, E.K. \& Mesler, M.R. (2000). Evidence for natural selection in a fern hybrid zone. American Journal of Botany, 87: 1168-1174.

Klein, E.K., Lagache-Navarro, L. \& Petit, R.J. (2017). Demographic and spatial determinants of hybridization rate. Journal of Ecology, 105: 29-38.

Krajmerova, D., Paule, L., Zhlev, P., Volekova, M., Evtimov I. et al. (2016). Natural hybridization in Eastern-Mediterranean firs: the case of Abies borisiiregis. Plant Biosystems, 150: 1189-1199.
Krutovskii, K.V. \& Bergmann, F. (1995). Introgressive hybridization and phylogenetic relationships between Norway, Picea abies (L.) Karst. and Siberian, $P$. obovate Ledeb., spruce species studied by isozyme loci. Heredity, 74: 464-480.

Larcombe, M.J., Costa e Silva, J., Tilyard, P., Gore, P. \& Potts, B.M. (2016). On the persistence of reproductive barriers in Eucalyptus: the bridging of mechanical barriers to zygote formation by F1 hybrids is counteracted by intrinsic post-zygotic incompatibilities. Annals of Botany, 118: 431-444.

Leong Pock Tsy, J-M., Lumaret, R., Flaven-Noguier, E., Sauve, M., Dubois, M-P. \& Danthu, P. (2013). Nuclear microsatellite variation in Malagasy baobabs (Adansonia, Bombacoideae, Malvaceae) reveals past hybridization and introgression. Annals of Botany, 112: 1759-1773.

Lepais, O. \& Gerber, S. (2010). Reproductive patterns shape introgression within the European white oak species complex. Evolution, 65: 156-170.

Lepais, O., Roussel, G., Hubert, F., Kremer, A. \& Gerber, S. (2013). Strength and variability of postmating reproductive isolating barriers between four European white oak species. Tree Genomics \& Genomes, 9: 841853.

Lexer, C., Joseph, J.A., van Loo, M., Barbara, T., Heinze, B. et al. (2010). Genomic admixture analysis in European Populus spp. reveals unexpected patterns of reproductive isolation and mating. Genetics, 186: 699712.

Lindtke, D., Buerkle, C.A., Barbara, T., Heinze, B., Castiglione, et al. (2012). Recombinant hybrids retain heterozygosity at many loci: new insights into genomics of reproductive isolation in Populus. Molecular Ecology, 21: 5042-5058.

Little, D.P. (2004). Documentation of hybridization between Californian cypresses: Cupressus macnabiana $\mathrm{x}$ sargentii. Systematic Botany, 29: 825-833.

Lopes, I.F., Del Lama, M.A. \& Del Lama, S.N. (2007). Genetic variability in three Amazon parrot species. Brazilian Journal of Biology, 67: 883-887.

Lumaret, R. \& Jabbour-Zahab, R. (2009). Ancient and current gene flow between two distantly related Mediterranean oak species, Quercus suber and Q. ilex. Annals of Botany, 102: 442-452. 
Ma, X-F, Szmidt, A.E. \& Wang, X-R. (2006). Genetic structure and evolutionary history of a diploid hybrid pine Pinus densata inferred from the nucleotide variation at seven gene loci. Molecular Biology and Evolution, 23: 807-816.

Mable, B.K., Alexandrou, M.A. \& Taylor, M.I. (2011). Genome duplication in amphibians and fish: an extended synthesis. Journal of Zoology, 284: 151-182.

Macaya-Sanz, D., Suter, L., Joseph, J., Barbara, T., Alba, N. et al. (2011). Genetic analysis of post-mating reproductive barriers in hybridizing European Populus species. Heredity, 107: 478-486.

Majure, L.C., Puente, R., Griffith, M.P., Judd, W.S., Soltis, P.S. \& Soltis, D.E. (2012). Phylogeny of Opuntia s. s. (Cactaceae): Clade delineation, geographic origins, and reticulate evolution. American Journal of Botany, 99: 847-864.

Mallet, J. (2008). Hybridization, ecological races and the nature of species: empirical evidence for the ease of speciation. Philosophical Transactions of the Royal Society B, 363: 2971-2986.

Manuel (de), M., Kuhlwilm, M., Frandsen, P., Sousa, V.C., Desai, T. et al. 2016. Chimpanzee genomic diversity reveals ancient admixture with bonobos. Science, 354: 477-481.

Mao, J-F. \& Wang, X-R. (2011). Distinct niche divergence characterizes the homoploid hybrid speciation of Pinus densata on the Tibetan Plateau. The American Naturalist, 177: 424-439.

Matos, J.A. \& Schaal, B.A. (2000). Chloroplast evolution in the Pinus montezumae complex: a coalescent approach to hybridization. Evolution, 54: 1218-1233.

Mavárez, J. \& Linares, M. (2008). Homoploid hybrid speciation in animals. Molecular Ecology, 17: 41814185 .

McKinnon, G.E., Jordan, G.J., Vaillancourt, R.E., Steane, D.A. \& Potts, B.M. (2004a). Glacial refugia and reticulate evolution: the case of the Tasmanian eucalypts. Philosophical Transactions of the Royal Society of London B, 359: 275-284.

McKinnon, G.E., Vaillancourt, R.E., Steane, A. \& Potts, B.M. (2004b). The rare silvergum, Eucalyptus cordata, is leaving its trace in the organellar gene pool of Eucalyptus globulus. Molecular Ecology, 13: 3751-3762.
McKinnon, G.E., Smith, J.J. \& Potts, B.M. (2010). Recurrent nuclear DNA introgression accompanies chloroplast DNA exchange between two eucalypt species. Molecular Ecology, 19: 1367-1380.

Melo, M. \& O’Ryan, C. (2007). Genetic differentiation between Príncipe Island and mainland populations of the grey parrot (Psittacus erithacus), and implications for conservation. Molecular Ecology, 16: 1673-1685.

Messaoudène, M., Labiri, M. \& Derridj, A. (2007). Etude de la diversité floristique de la forêt de l'Akfadou (Algérie). Bois et Forêts des tropiques, 291: 75-81.

Mhamdi, S., Brendel, O., Montpied, P., GhouilAmimi, H., Hasnaoui, I. \& Dreyer, E. (2013). Leaf morphology displays no detectable special organization in the relict Quercus afares Pomel compared to the cooccurring parental species $Q$. canariensis Willd. and $Q$. suber L. Annals of Forest Science 79: 675-684.

Mir, C., Toumi, L., Jarne, P., Sarda, V., Di Giusto, F. \& Lumaret, R. (2006). Endemic North African Quercus afares Pomel originates from hybridization between two genetically very distant oak species $(Q$. suber $\mathrm{L}$. and $Q$. canariensis Willd.): evidence from nuclear and cytoplasmic markers. Heredity, 96: 175-184.

Miralles, L., Lens, S., Rodríguez-Folgar, A., Carrillo, M., Martin, V., Mikkelsen, B. \& Garcia-Vazquez, E. (2013). Interspecific introgression in cetaceans: DNA markers reveal post-F1 status of pilot whale. PLoS ONE, 8(8): e69511, doi:10.1371/journal. pone.0069511.

Miralles, L., Oremus, M., Silva, M.A., Planes, S. \& Garcia-Vázquez, E. (2016). Interspecific hybridization in pilot whales and asymmetric genetic introgression in Northern Globicephala melas under the scenario of global warming. PLoS ONE, 11(8): e0160080. doi:10.1371/journal.pone. 0160080.

Moe, A.M. \& Weiblen, G.D. (2012). Pollinator-mediated reproductive isolation among dioecious fig species (Ficus, Moraceae). Evolution, 66: 3710-3721.

Möller, M., Gao, L-M., Mill, R.R., Liu, J., Zang, D-Q., et al. (2013). A multidisciplinary approach reveals hidden taxonomic diversity in the morphologically challenging Taxus wallichiana complex. Taxon, 62: 1161-1177.

Moran, E.V., Willis, J. \& Clark, J.S. (2012). Genetic evidence for hybridization in red oaks (Quercus sect. Lobatae, Fagaceae). American Journal of Botany, 99: 92-100. 
Morin, P.A., Archer, F.I., Foote, A.D., Vilstrup, J., Allen, E.E., Wade, P., et al. (2010). Complete mitochondrial genome phylogeographic analysis of killer whales (Orcinus orca) indicates multiple species. Genome Research, 20: 908-916.

Morris, W.F., Pfister, C.A., Tuljapurkar, S., Haridas, C.V., Boggs, C.L. et al. (2008). Longevity can buffer plant and animal populations against changing climatic variability. Ecology, 89: 19-25.

Mullenniex, A., Hardig, T.M. \& Mesler, M.R. (1998). Molecular confirmation of hybrid swarms in the fern genus Polysticum (Dryopteridaceae). Systematic Botany, 23: 421-426.

Neophytou, C., Aravanopoulos, F.A., Fink, S. \& Dounavi, A. (2011). Interfertile oaks in an island environment. II. Limited hybridization between Quercus alnifolia Poech and Q. coccifera L. in a mixed stand. European Journal of Forest Research, 130: 623-635.

Oh, S-H, Youm, J-W, Kim, Y-I \& Kim, Y-D. (2016). Phylogeny and evolution of endemic species on Ulleungdo island, Korea: the case of Fagus multinervis (Fagaceae). Systematic Botany, 41: 617-625.

O’Mullan, G.D., Maas, P.A.Y., Lutz, R.A. \& Vrijenhoek, R.C. (2001). A hybrid zone between hydrothermal vent mussels (Bivalvia: Mytilidae) from the MidAtlantic Ridge. Molecular Ecology, 10: 2819-2831.

Ortego, J., Gugger, P.F. \& Sork, V.L. (2017). Impacts of human-induced environmental disturbances on hybridization between two ecologically differentiated Californian oak species. New Phytologist, 213: 942-955.

Orr, H.A. \& Unckless, R.L. (2008). Population extinction and the genetics of adaptation. American Naturalist, $172: 160-169$.

Pacheco-Sierra, G., Gompert, Z., Domínguez-Laso, J. \& Vászquez-Domínguez, E. (2016). Genetic and morphological evidence of a geographically widespread hybrid zone between two crocodile species, Crocodylus acutus and Crocodylus moreletii. Molecular Ecology, 25: 3484-3498.

Palma-Otal, M., Moore, W.S., Adams, R.P., \& Joswiak, G.R. (1983). Morphological, chemical, and biogeographical analyses of a hybrid zone involving Juniperus virginiana and J. horizontalis in Wisconsin. Canadian Journal of Botany, 61: 2733-2746.
Pampoulie, C. \& Daníelsdóttir, A.K. (2008). Resolving species identification problems in the genus Sebastes using nuclear genetic markers. Fisheries Research, 93: 54-63.

Papageorgiou, A.C., Vidalis, A., Gailing, O., Tsiripidis, I., Hatziskakis, S., et al. (2008). Genetic variation of beech (Fagus sylvatica L.) in Rodopi (N.E. Greece). European Journal of Forest Research, 127: 81-88.

Parham, J.F., Papenfuss, T.J., Van Dijk, P.P., Wilson, B.S., Marte, C., Schettino, L.R., \& Simison, W.B. (2013). Genetic introgression and hybridization in Antillean freshwater turtles (Trachemys) revealed by coalescent analyses of mitochondrial and cloned nuclear markers. Molecular Phylogenetics and Evolution, 67: 176-187.

Parrish, T.L., Koelewijn, H.P., van Dijk, P.J. \& Kruijt, M. (2003). Genetic evidence for natural hybridization between species of dioecious Ficus on island populations. Biotropica, 35: 333-343.

Patrut, A., von Reden, K.F., Danthu, P., Leong Pock Tsy, J-M, Patrut, R.T. \& Lowy D.A. (2015). Searching for the oldest baobab of Madagascar: radiocarbon investigation of large Adansonia rubrostipa trees. PLoS ONE, 10(3): e0121170. doi: 10.1371/journal. pone. 0121170 .

Peñaloza-Ramirez, J.M., Gonzalez-Rodriguez, A.G., Mendiza-Cuenca, L., Caron, H., Kremer, A. \& Oyama, K. (2010). Interspecific gene flow in a multispecies oak hybrid zone in the Sierra Tarahumara of Mexico. Annals of Botany, 105: 389-399.

Pfennig, K.S., Kelly, A.L. \& Pierce, A.A. (2016). Hybridization as a facilitator of species range expansion. Proceedings of the Royal Society B, 283: 2016.1329.

Pilot, M., Dahlheim, M.E. \& Hoelzel, A.R. (2010). Social cohesion among kin, geneflow without dispersal and the evolution of population genetic structure in the killer whale (Orcinus orca). Journal of Evolutionary Biology, 23: 20-31.

Poulakakis, N., Edwards, D.L., Chiari, Y., Garrick, R.C., Russello, M.A. et al. (2015). Description of a new Galapagos giant tortoise species (Chelonoidis; Testudines: Testudinidae) from Cerro Fatal on Santa Cruz Island. PLoS ONE 10(10): e0138779. Doi: $10.1371 /$ journal.pone. 0138779 . 
Pujolar, J.M., Jacobsen, M.W., Als, T.D., Frydenberg, J., Magnussen E. et al. (2014). Assessing patterns of hybridization between North Atlantic eels using diagnostic single-nucleotide polymorphisms. Heredity, 112: 626-637.

Racimo, F., Sankararaman, S., Nielsen, R. \& HuertaSánchez, E. (2015). Evidence for archaic adaptive introgression in humans. Nature Reviews Genetics, 16: 359-371.

Raemy, M., Fritz, U., Cheylan, M. \& Ursenbacher, S. (2017). Hybridization between turtle subspecies: a case study with the European pond turtle (Emys orbicularis). Conservation Genetics, 18: 287-296.

Ran, J-H, Shen, T-T, Liu, W-J, Wang, P-P \& Wang, X-Q (2015). Mitochondrial introgression and complex biogeographic history of the genus Picea. Molecular Phylogenetics and Evolution, 93: 63-76.

Realini, M.F., Gonzalez, G.E., Font, F., Picca, P.I., Poggio, L. \& Gottlieb, A.M. (2015). Phylogenetic relationships in Opuntia (Cactaceae, Opuntioideae) from southern South America. Plant Systematics and Evolution, 301: 1123-1134.

Rellstab, C., Zoller, S., Walthert, L., Lesur, I., Pluess, A.R., et al. (2016). Signatures of local adaptation in candidate genes of oaks (Quercus spp.) with respect to present and future climatic conditions. Molecular Ecology, 25: 5907-5924.

Ren, G-P, Abbott, R.J., Zhou, Y.F., Zhang, L-R, Peng, Y-L \& Liu, J-Q. (2012). Genetic divergence, range expansion and possible homoploid hybrid speciation among pine species in Northeast China. Heredity, 108: 552-562.

Rentsch, J.D. \& Leebens-Mack, J. (2012). Homoploid hybrid origin of Yucca gloriosa: intersectional hybrid speciation in Yucca (Agavoideae, Asparagaceae). Ecology and Evolution, 2: 2213-2222.

Riesch, R., Barrett-Lennard, L.G., Ellis, G.M., Ford, J.K.B. \& Deecke, V.B. (2012). Cultural traditions and the evolution of reproductive isolation: ecological speciation in killer whales? Biological Journal of the Linnean Society, 106: 1-17.

Rohwer, S., Harris, R.B. \& Walsh, H.E. (2014). Rape and the prevalence of hybrids in broadly sympatric species: a case study using albatrosses. PeerJ 2: e-409; DOI 10.7717/peerj.409.
Roques, S., Sevigny, J-M \& Bernatchez L. (2001). Evidence for broadscale introgressive hybridization between two redfish (genus Sebastes) in the north-west Atlantic: a rare marine example. Molecular Ecology, 10: 149-165.

Rushton, B.S. (1993). Natural hybridization within the genus Quercus L. Annales des Sciences Forestières, 50 (Suppl.1): 73-90.

Sahat, A., Johansen, T., Hedeholm, R., Nielsen, E., Westgaard, J-I. et al. (2017). Geographic extent of introgression in Sebastes mentella and its effect on genetic population structure. Evolutionary Applications, 10: 77-90.

Salvini, D., Bruschi, P., Fineschi, S., Grossoni, P., Kjaer, E.D. \& Vendramin, G.G. (2008). Natural hybridization between Quercus petraea (Matt.) Liebl. and Quercus pubescens Willd. within an Italian stand as revealed by microsatellite fingerprinting. Plant Biology, 11: 758-765.

Sánchez-Quinto, F. \& Lalueza-Fox, C. (2015). Almost 20 years of Neanderthal palaeogenetics: adaptation, admixture, diversity, demography and extinction. Philosophical Transactions of the Royal Society of London B: Biological Sciences, 370: 20130374.

Semerikov, V.L. \& Lascoux, M. (2013). Nuclear and cytoplasmic variation within and between Eurasian Larix (Pinaceae) species. American Journal of Botany, 90: 1113-1123.

Semerikova, S.A., Semerikov, V.L. \& Lascoux, M. (2011). Post-glacial history and introgression in Abies (Pinaceae) species of the Russian Far East inferred from both nuclear and cytoplasmic markers. Journal of Biogeography, 38: 326-340.

Sigel, E.M. (2016). Genetic and genomic aspects of hybridization in ferns. Journal of Systematics and Evolution, 54: 638-655.

Sonsthagen, S.A., Wilson, R.E., Chesser, R.T., Pons, J-M., Crochet, P-A., Driskell, A. \& Dove, C. (2016). Recurrent hybridization and recent origin obscure phylogenetic relationships within the 'white- headed' gull (Larus sp.) complex. Molecular Phylogenetics and Evolution, 103: 41-54.

Spinks, P.Q. \& Shaffer, H.B. (2009). Conflicting mitochondrial and nuclear phylogenies for the widely disjunct Emys (Testudines: Emididae) species complex, and what they tell us about biogeography and hybridization. Systematic Biology, 58: 1-20. 
Starr, T.N., Gadek, K.E., Yoder, J.B., Flatz, R. \& Smith, C.I. (2013). Asymmetric hybridization and gene flow between Joshua trees (Agavaceae: Yucca) reflect differences in pollinator host specificity. Molecular Ecology, 22: 437-449.

Staudt, M., Mir, C., Joffre, R., Rambal, S., Bonin, A., Landais, D. \& Lumaret, R. (2004). Isoprenoid emissions of Quercus spp. (Q. suber and Q. ilex) in mixed stands contrasting in interspecific genetic introgression. New Phytologist, 163: 573-584.

Stelkens, R.B., Brockhurst, M.A., Hurst, G.D.D. \& Greig, D. (2014). Hybridization facilitates evolutionary rescue. Evolutionary Applications, 7: 1209-1217.

Sternkopf, V., Liebers-Helbig, D., Ritz, M.S., Zhang, J., Helbig, A.J; \& de Knijff, P. (2010). Introgressive hybridization and the evolutionary history of the herring gull complex revealed by mitochondrial and nuclear DNA. BMC Evolutionary Biology, 10: 348.

Suarez-Gonzalez, A., Hefer, C.A., Christe, C., Corea, O., Lexer, C. et al. (2016). Genomic and functional approaches reveal a case of adaptive introgression from Populus balsamifera (balsam poplar) in P. trichocarpa (black cottonwood). Molecular Ecology, 25: 2427-2442.

Sun, Y., Abbott, R.J., Li, L., Zou, J. \& Liu, J. (2014). Evolutionary history of Purple cone spruce (Picea purpurea) in the Qinghai-Tibet Plateau: homoploid hybrid origin and Pleistocene expansion. Molecular Ecology, 23: 343-359.

Tessier, L., Nola, P. \& Serre-Bachet, F. 1994. Deciduous Quercus in the Mediterranean region: tree-ring/ climate relationships. New Phytologist, 126: 355-367.

Terry, R.G. (2010). Re-evaluation of morphological and chloroplast DNA variation in Juniperus osteosperma (Torr.) Little and Juniperus occidentalis Hook (Cupressaceae) and their putative hybrids. Biomemical Systematics and Ecology, 38: 349-360.

Terry, R.G., Nowak, R.S. \& Tausch, R.J. (2000). Genetic variation in chloroplast and nuclear ribosomal DNA in Utah Juniper (Juniperus osteosperma, Cupressaceae): evidence for interspecific gene flow. American journal of Botany, 87: 250-258.

Truffaut, L., Chancerel, E., Ducousso, A., Dupouy, J.C., Badeau, V. et al. (2017). Fine-scale species distribution changes in a mixed oak stand over two successive generations. New Phytologist, 215: 126-139.
Tsuda, Y., Chen, J., Stocks, M., Källman, T., Sonstebo, et al. (2016). The extent and meaning of hybridization and introgression between Siberian spruce (Picea obovate) and Norway spruce (Picea abies): cryptic refugia as stepping stones to the west? Molecular Ecology, 25: 2773-2789.

Tsuda, Y., Semerikov, V., Sebastiani, F., Vendramin, G.G. \& Lascoux, M. (2017). Multispecies genetic structure and hybridization in the Betula genus across Eurasia. Molecular Ecology, 26: 589-605.

Tsutsumi, C., Matsumoto, S., Yatabe-Kakugawa, Y., Hirayama, Y. \& Kato, M. (2011). A new allotetraploid species of Osmunda (Osmundaceae). Systematic Botany, 36: 836-844.

Ungerer, M.C., Baird, S.J.E., Pan, J. \& Rieseberg, L.H. (1998). Rapid hybrid speciation in wild sunflowers. Proceeding of the National Academy of Science U.S.A., 95: 11757-11762.

Valencia-Cuevas, L., Mussali-Galante, P., Piñero, D., Castillo-Mendoza, E., Rangel-Altamirano, G. \& TovarSanchez, E. (2015). Hybridization of Quercus castanea (Fagaceae) across a red oak species gradient in Mexico. Plant Systematics and Evolution, 301: 1085-1097.

Valentin, A., Sévigny, J-M., Morin, B., Power, D. \& Branton, R.M. Extensive sampling and concomitant use of meristic characteristics and variation at the $M D H-A$ Locus reveal new information on redfish species distribution and spatial pattern of introgressive hybridization in the Northwest Atlantic. Journal of Northwest Atlantic Fishery Science, 36: 65-80.

Vallejo-Marin, M. \& Hiscock, S.J. (2016). Hybridization and hybrid speciation under global change. New Phytologist, 211: 1170-1187.

Vanden Broeck, A., Villar, M., Van Bockstaele, E., \& Van Slycken, J. (2005). Natural hybridization between cultivated poplars and their wild relatives: evidence and consequences for native poplar populations. Annals of Forest Science, 62: 601-613.

Vander Wall, E., Garant, D., Festa-Bianchet, M. \& Pelletier, F. (2013). Evolutionary rescue in vertebrates: evidence, applications and uncertainty. Philosophical Transactions of the Royal Society B, 368: 20120090.

Vilaça, S.T., Vargas, S.M., Lara-Ruiz, P.L., Molfetti, E., Reis, E.C. et al. (2012). Nuclear markers reveal a complex introgression pattern among marine turtle species on the Brazilian coast. Molecular Ecology, 21: 4300-4312. 
Wachowiak, W., Zukowska, W.B., Wójkiewicz, B., Cavers, S. \& Litkowiec, M. (2016). Hybridization in contact zone between temperate European pine species. Tree Genetics \& Genomes, 12: 48.

Watano, Y., Kanai, A. \& Tani, N. (2004). Genetic structure of hybrid zones between Pinus pumila and P. parviflora var. pentaphylla (Pinaceae)) revealed by molecular hybrid index analysis. American Journal of Botany, 91: 65-72.

Wang, B., Mao, J.F., Gao, J., Zhao, W. \& Wang, X.R. (2011). Colonization of the Tibetan Plateau by the homoploid hybrid pine Pinus densata. Molecular Ecology, 20: 3796-3811.

Wang, Z., Du, S., Dayanandan, S., Wang, D., Zeng, Y. \& Zhang, J. (2014). Phylogeny reconstruction and hybrid analysis of Populus (Salicaceae) based on nucleotide sequences of multiple single-copy nuclear genes and plastid fragments. PloS ONE, 9: e103645. Doi: 10.1371/journal.pone.0103645.

Wei, X.X. \& Wang, X.Q. (2003). Phylogenetic split of Larix: evidence from paternally inherited cpDNA trnT-trnF region. Plant Systematics and Evolution, 239: 67-77.

Wei, Z.D., Kobmoo, N., Cruaud, A \& Kjellberg, F. (2014). Genetic structure and hybridization in the species group of Ficus auriculata: can closely related sympatric Ficus species retain their genetic identity while sharing pollinators? Molecular Ecology, 23: 35383550 .

Welter, S., Bracho-Nuñez, A., Mir, C., Zimmer, I., Kesselmeier, J. et al. (2012). The diversification of terpene emissions in Mediterranean oaks: lessons from a study of Quercus suber, Quercus canariensis and its hybrid Quercus afares. Tree Physiology, 32: 1082-1091.
Wen, D., Yu, Y. \& Nakhleh, L. (2016). Bayesian inference of reticulate phylogenies under the multispecies network coalescent. PLoS genetics, 12:e1006006.

Wielgoss, S., Gilabert, A., Meyer, A. \& Wirth, T. (2014). Introgressive hybridization and latitudinal admixture clines in North Atlantic eels. BMC Evolutionary Biology, 14: 61 .

Xiang, Q.-P., Wei, R., Shao, Y.-Z., Yang, Z.-Y., Wang, X.Q. \& Zhang X.-C. (2015). Phylogenetic relationships, possible ancient hybridization, and biogeographic history of Abies (Pinaceae) based on data from nuclear, plastid, and mitochondrial genomes. Molecular Phylogenetics and Evolution, 82: 1-14.

Yakimowski, S.B. \& Riesrberg, L.H. (2014). The role of homoploid hybridization in evolution: a century of studies synthesizing genetics and ecology. American Journal of Botany, 101: 1247-1258.

Yatebe, Y. Tsutsumi, C., Hirayama, Y., Mori, K., Murakami, N. \& Kato, M. (2009). Genetic population structure of Osmunda japonica, rheophilous Osmunda lancea and their hybrids. Journal of Plant Research, 122: 585-595.

Zhong, B., Fong, R., Collins, L.J., McLenachan, P.A. \& Penny, D. (2014). Two new fern chloroplasts and decelerated evolution linked to the long generation time in tree ferns. Genome Biology and Evolution, 6: 1166-1173.

Zohren, J., Wang, N., Kardailsky, I., Borrell, J., Joecker, A. et al. (2016). Unidirectional diploid-tetraploid introgression among British birch trees with shifting ranges shown by restriction site-associated markers. Molecular Ecology, 25: 2413-2426. 
Este número ha recibido una ayuda del Vicerrectorado de Investigación y Transferencia de Conocimiento de la Universidad de Alicante
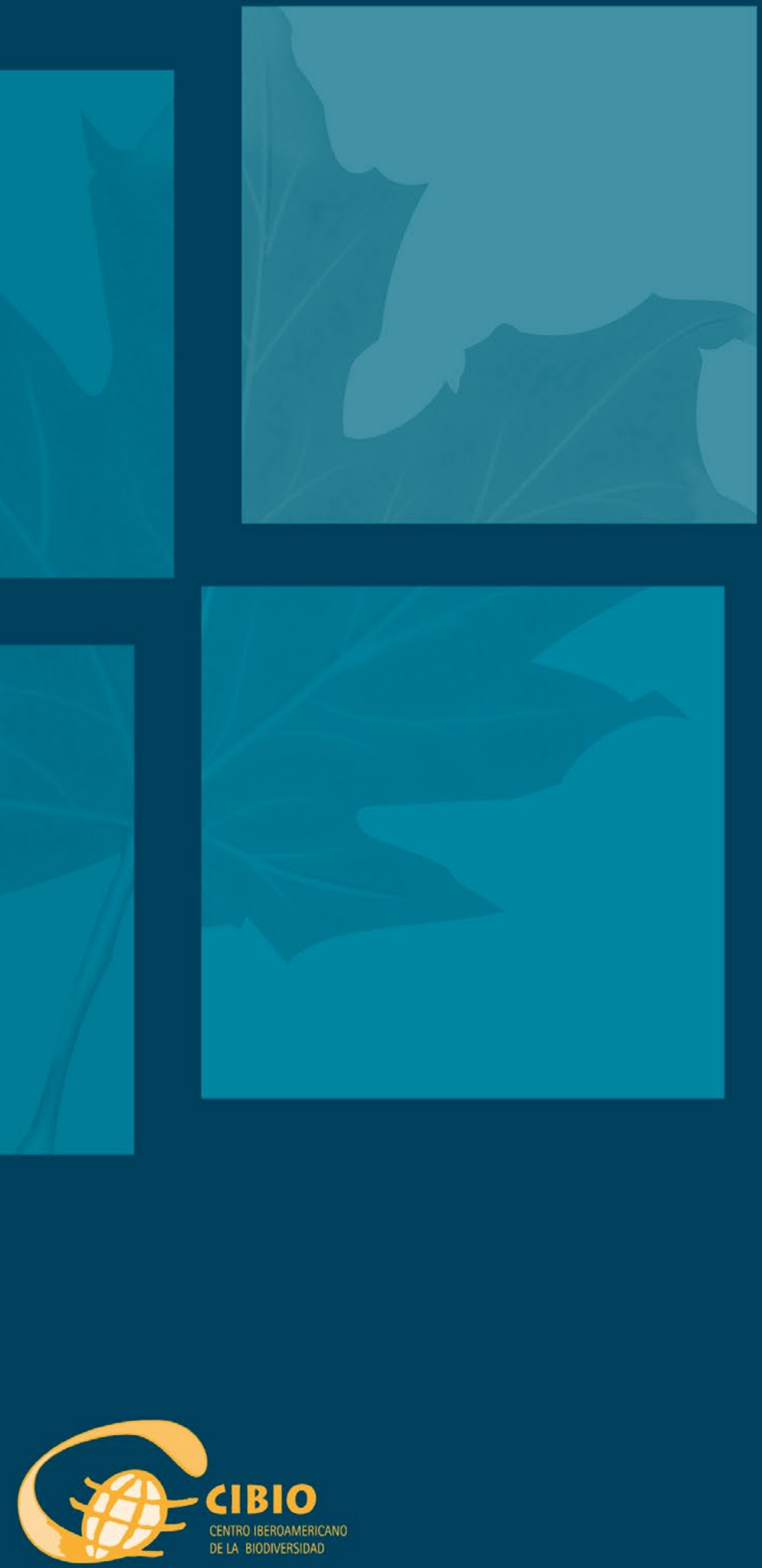

\section{Universitat d'Alacant
Universidad de Alicante}

